\title{
ANALISA KEPUASAN KERJA, KOMITMEN ORGANISASI DAN LINGKUNGAN KERJA TERHADAP TURNOVER INTENTION KARYAWAN (Studi Kasus Pada Karyawan Bagian Sewing PT Dan Liris)
}

\author{
Resha Dwi Khotimah, Djumali, Supawi Pawenang \\ Fakultas Ekonomi Universitas Islam Batik Surakarta \\ Email: reshadwik@gmail.com
}

\begin{abstract}
This study aims to examine the effect of simultaneous and partial of job satisfaction, organizational commitment and work environment as an independent variable on employee turnover intention as the dependent variable. The methodology of this research uses quantitative descriptive. The sampling technique using simple random sampling obtained a sample of 100 employees of PT Dan Liris Sewing section. Data collection using a questionnaire while the data analysis method used is multiple linear regression analysis processed with the help of SPSS version 24. The results showed: (1) F test results showed that job satisfaction, organizational commitment and work environment simultaneously had a positive and significant effect on employee turnover intention at PT Dan Liris. (2) Based on the partial test results the job satisfaction variable has a positive and not significant effect on employees of Sewing section at PT Dan Liris. (3) Based on the partial test results the organizational commitment variable has a positive and not significant effect on employees of Sewing section at PT Dan Liris. (4) Based on the partial test results the work environment variable has a positif and significant effect on employees of Sewing section at PT Dan Liris.
\end{abstract}

Keywords: Job Satisfaction, Organizational Commitment, Work Environment, Turnover Intention

\section{PENDAHULUAN}

Kemajuan dan berkembangnya dunia bisnis dewasa ini memaksa setiap perusahaan bersaing secara ketat supaya kelangsungan hidup bisnisnya dapat bertahan. Perusahaan harus bersaing satu sama lainnya untuk mendapatkan profit dengan memanfaatkan semua potensi sumber daya yang dimiliki dan meningkatkan kinerja perusahaan secara maksimal. Manajemen yang baik dan efektif dalam mengelola semua sumber daya merupakan strategi dalam meningkatkan kinerja perusahaan.

Salah satu permasalahan terkait pengelolaan sumber daya manusia yaitu adanya tingkat turnover intention karyawan. Wirawan (2015) menjelaskan bahwa turnover merupakan karyawan berhenti dari suatu perusahaan kemudian meninggalkan kerja/pindah ke perusahaan lainnya dengan berbagai alasan. Turnover merupakan hal umum, namun jika tingkat turnover karyawan terlampau tinggi maka akan berakibat pada aktifitas operasional dan produktivitas perusahaan terganggu, serta akan menimbulkan biaya-biaya seperti perekrutan, seleksi, dan training untuk mendapatkan karyawan pengganti. Beberapa literatur dan penelitian yang telah ada menunjukkan bahwa terdapat beberapa penyebab terjadinya turnover intention yaitu kepuasan kerja, komitmen organisasi dan lingkungan kerja.

Kepuasan kerja merupakan kondisi emosi atau perasaan senang atas penilaian dan pengalaman kerja seseorang (Luthans, 2006: 243). Ketidakpuasan kerja karyawan akan 
menyebabkan rendahnya motivasi bekerja sehingga produktivitas kerja menurun, tingkat absensi tinggi. Faktor lain menurut Robbins (2008:142) yaitu komitmen organisasi yang didefinisikan sebagai kondisi ketika karyawan menempatkan dirinya untuk berpihak pada suatu perusahaan tertentu, berkeinginan untuk bertahan sebagai bagian dari perusahaan tersebut. Selain kepuasan kerja dan komitmen organisasi, lingkungan kerja juga dapat mempengaruhi turnover intention. Fuaidah, dkk (2018) menerangkan bahwa terdapat dua jenis lingkungan, yaitu lingkungan fisik karyawan meliputi keadaan tempat kerja seperti luas ruangan kerja, suhu ruang kerja, penerangan, tingkat kebisingan, dan lain sebagainya. Adapun lingkungan non fisik yaitu interaksi sehari-hari yang dilakukan antar karyawan dan dapat berupa budaya yang diciptakan oleh perusahaan.

PT Dan Liris merupakan perusahaan yang bergerak dalam bidang tekstil dan garmen yang menghasilkan produk dan benang yang berkualitas dan mengirimkannya ke pasar domestik hingga ke pasar internasional. Seiring dengan perluasan bisnis yang dilakukan dan tuntutan target yang tinggi, maka untuk menjaga kelangsungan berjalannya proses produksi dan mencegah terjadinya turnover intention karyawan, maka PT Dan Liris harus memperhatikan beberapa penyebab yang dapat menimbulkan turnover intention yaitu kepuasan kerja, komitmen organisasi dan lingkungan kerja pada karyawan.

Berdasarkan uraian diatas, penulis berpendapat layak melakukan penelitian dengan mengambil judul "Analisa Kepuasan Kerja, Komitmen Organisasi dan Lingkungan Kerja Terhadap Turnover Intention Karyawan (Studi Kasus Pada Karyawan Bagian Sewing PT Dan Liris)".

\section{TINJAUAN PUSTAKA}

a. Kepuasan Kerja

Firdaus (2017) menjelaskan pendapat Handoko (2007) bahwa kepuasan kerja merupakan keadaan emosi senang maupun tidak senang karyawan dalam memandang pekerjaannya. Menurut Rismayanti dkk (2018) indikator untuk mengetahui kepuasan kerja yaitu puas terhadap pekerjaan, upah, kesempatan promosi, pengawasan atasan, dan rekan kerja.

\section{b. Komitmen Organisasi}

Koesmono (2007) menjelaskan bahwa komitmen organisasi yaitu level kepercayaan karyawan dalam memahami tujuan organisasi dan ingin untuk tetap berada dalam lingkungan organisasi tersebut. Firdaus (2017) mengungkapkan pendapat.Meyer dan Allen bahwa ada tiga indikator untuk menilai komitmen karyawan yaitu komitmen afektif, kelanjutan dan normatif.

\section{c. Lingkungan Kerja}

Sedarmayanti (2001) mengartikan lingkungan kerja yaitu segala bentuk alat dan material yang berada di lingkungan sekitar karyawan bekerja serta standar prosedur kerja individu maupun tim. Lingkungan kerja dibagi menjadi 2 bentuk, sebagai berikut:

- Lingkungan fisik yaitu keadaan fisik di sekitar tempat kerja yang dapat berpengaruh kepada karyawan secara langsung maupun tidak langsung. Unsur dari lingkungan kerja ini meliputi pencahayaan, suhu, sirkulasi udara, tata warna, kebisingan, keamanan dan lainnya.

- Lingkungan non fisik yaitu suasana yang tercipta melalui hubungan kerja antara semua level karyawan. 


\section{d. Turnover Intention}

Rismayanti dkk (2018) mengungkapkan pendapat Siregar (2006: 214) bahwa turnover intention yaitu niat karyawan yang mengarah meninggalkan pekerjaannya dengan sukarela atas pilihan mereka sendiri. Menurut Hafiz dkk (2016) ada 3 indikator untuk mengetahui keinginan berpindah karyawan, yaitu:

- Keinginan untuk keluar (Intention to quit): karyawan yang berniat meninggalkan pekerjaan akan tercermin melalui sikapnya selama bekerja, dimulai dengan tingkat absensi dan mangkir yang tinggi sebelum seorang karyawan mengambil keputusan untuk keluar dari perusahaan.

- Keinginan untuk mencari pekerjaan lain (Intention to search another job): karyawan mulai berkeinginan mendapatkan pekerjaan lain, biasanya tercermin ketika mereka mencari tambahan di luar perusahaan.

- Pikiran untuk berhenti (Thoughts of quit): karyawan akan memikirkan resiko keuntungan dan kerugian sebelum mereka memutuskan untuk tetap bertahan pada lingkungan pekerjaannya atau meninggalkan pekerjaannya.

\section{METODOLOGI PENELITIAN}

\section{a. Desain Penelitian}

Penelitian ini merupakan penelitian deskriptif-kuantitatif dikarenakan data yang akan dipakai untuk menganalisa hasil dan kesimpulan dari penelitian ini dinyatakan dengan angka. Sumber data menggunakan data primer dan sekunder. Penelitian ini menjelaskan pengaruh langsung dari variabel bebas yang diteliti yaitu kepuasan kerja, komitmen organisasi dan lingkungan kerja terhadap turnover intention karyawan.

\section{b. Teknik Sampling}

Penelitian ini dilaksanakan di satu unit bagian Sewing PT Dan Liris dengan populasi 500 orang. Adapun teknik pengambilan sampel menggunakan simple random sampling sejumlah 100 orang.

\section{c. Teknik Pengumpulan Data}

Teknik pengumpulan data melalui wawancara, kuesioner, observasi, dokumentasi dan studi kepustakaan. Sedangkan pengukuran kuesioner menggunakan skala Likert.

\section{HASIL DAN PEMBAHASAN}

\section{a. Uji Instrumen}

1) Uji Validitas

Hasil uji validitas menunjukkan bahwa masing-masing pernyataan menghasilkan nilai rhitung > rtabel (rhitung $>0,444$ ). Sehingga disimpulkan bahwa item-item pernyataan pada variabel kepuasan kerja, komitmen organisasi, lingkungan kerja dan turnover intention dinyatakan valid.

\section{2) Uji Reliabilitas}

Data dinyatakan reliabel/andal jika nilai Cronchbrach Alpha $>0,6$. Berdasarkan hasil uji reliabilitas didapatkan nilai Cronchbrach Alpha $>0,6$ sehingga semua variabel dinyatakan reliabel/andal. Berikut tabel hasil pengujian reliabilitas: 
Hasil uji Reliabilitas

\begin{tabular}{cccc}
\hline Variabel & Croncbach's Alpha & Alpha & Keterangan \\
\hline Kepuasan Kerja & 0,708 & 0,6 & Reliabel \\
Komitmen Organisasi & 0,743 & 0,6 & Reliabel \\
Lingkungan Kerja & 0,732 & 0,6 & Reliabel \\
Turnover Intention & 0,735 & 0,6 & Reliabel \\
\hline
\end{tabular}

\section{b. Teknik Analisa Data}

\section{1) Uji Asumsi Klasik}

a. Uji Normalitas

Uji normalitas dilakukan untuk menguji model regresi berganda (variabel terikat dan variabel bebas) harus mempunyai distribusi data normal atau mendekati normal (Ghozali,2011). Uji normalitas data menggunakan grafik normal plot dengan asumsi:

- Apabila data yang menyebar disekitar garis diagonal dan mengikuti arah garis diagonal/ grafik histogramnya, maka menunjukkan pola distribusi data normal

- Apabila data menyebar jauh dari garis diagonal dan tidak mengikuti arah garis diagonal atau grafik histogramnya, maka tidak menunjukkan pola distribusi data normal.

\section{b. Uji Multikolinieritas}

Ghozali (2011:105) uji multikolinieritas merupakan uji untuk mengetahui ada tidaknya masalah multikolinierias pada model regresi, sebagai berikut:

- Memiliki angka tolerance $>0,10$

- Memiliki nilai VIF<10

Tabel 4.11

Hasil Uji Multikolinieritas

\begin{tabular}{|c|c|c|c|c|c|}
\hline Variabel & $\begin{array}{c}\text { Toleranc } \\
\mathrm{e}\end{array}$ & Kriteria & VIF & Kriteria & Kesimpulan \\
\hline $\begin{array}{c}\text { Kepuasan } \\
\text { Kerja }\end{array}$ & 0,958 & $>0,10$ & 1,043 & $<10$ & $\begin{array}{c}\text { Tidak terjadi } \\
\text { multikolinieritas }\end{array}$ \\
\hline $\begin{array}{l}\text { Komitmen } \\
\text { Organisasi }\end{array}$ & 1,000 & $>0,10$ & 1,000 & $<10$ & $\begin{array}{c}\text { Tidak terjadi } \\
\text { multikolinieritas }\end{array}$ \\
\hline $\begin{array}{c}\text { Lingkungan } \\
\text { Kerja }\end{array}$ & 0,959 & $>0,10$ & 1,043 & $<10$ & $\begin{array}{c}\text { Tidak terjadi } \\
\text { multikolinieritas }\end{array}$ \\
\hline
\end{tabular}

Berdasarkan hasil uji multikolinieritas diatas menunjukkan bahwa nilai tolerance masing-masing variabel $>0,10$. Sedangkan nilai VIF masing-masing variabel kerja <10. Sehingga disimpulkan bahwa tidak terjadi masalah multikolinieritas.

\section{c. Uji Heteroskedastisitas}

Uji Heteroskedastisitas digunakan untuk menguji model regresi apakah terjadi perbedaan variansi residual satu pengamatan ke pengamatan lain (Ghozali:2013). Berikut dasar analisis uji heteroskedastisitas:

- Apabila terdapat pola tertentu, seperti titik-titik yang membentuk pola teratur (bergelombang, melebar lalu menyempit), maka dinyatakan terjadi heteroskedastisitas. 
- Apabila tidak terlihat pola yang jelas dan menyebar diatas serta dibawah angka 0 pada sumbu Y, maka dinyatakan tidak terjadi heteroskedastisitas.

Berikut hasil uji heteroskedastisitas:

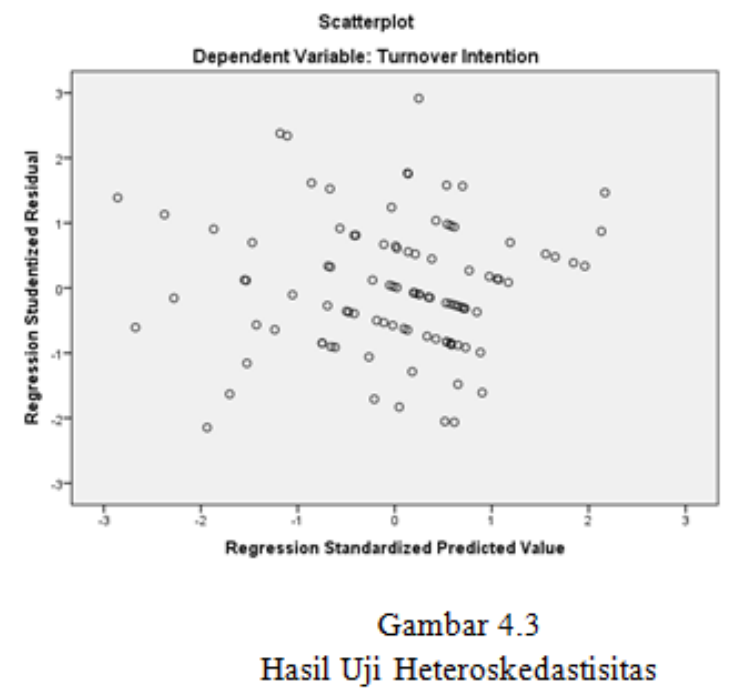

\section{d. Uji Autokorelasi}

Uji autokorelasi dilakukan untuk mengetahui model regresi linier terdapat korelasi antara periode t dengan periode t-1 (sebelumnya).

Tabel 4.12

Hasil Uji Autokorelasi

\begin{tabular}{cccc}
\hline DL & DU & DW & Keterangan \\
\hline 1,55 & 1.67 & 1,679 & Tidak terjadi Autokorelasi \\
\hline
\end{tabular}

Berdasarkan tabel diatas didapatkan nilai uji Durbin-Watson sebesar 1,679. Jika dilihat dari tabel Durbin-Watson, maka nilai $\mathrm{DU}=\mathrm{k} 1,67$ dan nilai $\mathrm{DL}$ $=1,55$. Apabila nilai Durbin Watson $>$ DU $(1,679>1.67)$ maka tidak terdapat autokorelasi. .

\section{2) Hipotesa}

\section{a. Analisis Regresi Linier Berganda}

Analisis regresi disesuaikan berdasarkan analisis data yang dipakai, karena tujuan analisis ini yaitu memprediksi hubungan sebab akibat antara variabel bebas dan variabel terikat. Sehingga penelitian ini menggunakan multiple linier regression (analisis regresi berganda) dan berikut hasil analisisnya:

Tabel 4.13

Hasil Uji Regresi Linier Berganda

\begin{tabular}{cc}
\hline Model & $\mathrm{B}$ \\
\hline (Constant) & 11,700 \\
Kepuasan Kerja & 0,088 \\
Komitmen Organisasi & 0,028 \\
Lingkungan Kerja & 0,333 \\
\hline
\end{tabular}


Berdasarkan tabel tersebut, uji analisis regresi berganda menggunakan SPSS 24, maka persamaannya seperti berikut:

$$
\mathrm{Y}=11,700+0,088 \mathrm{X} 1+0,028 \mathrm{X} 2+0,333 \mathrm{X} 3
$$

\section{b. Uji F (Uji Simultan)}

Uji ini dilakukan untuk menunjukkan pengaruh secara simultan (bersama-sama) variabel independen terhadap variabel independen. Berikut hasil perhitungan uji F:

Tabel 4.14

Hasil Uji F

\begin{tabular}{cccc}
\hline Model & F & Sig. & Kesimpulan \\
\hline Uji F & 6,730 & 0,000 & Diterima \\
\hline
\end{tabular}

\section{c. Uji t (UjiiParsial)}

Uji t atau disebut uji signifikansi parameter individu merupakan uji untuk mengetahui pengaruh variabel independen terhadap variabel independen. Apabila nilai level of significance thitung dari hasil perhitungan $<0,05$ maka Ho diterima.

Tabel 4.15

Hasil Uji t

\begin{tabular}{cccc}
\hline Variabel & $\mathrm{T}$ & Sig. & Kesimpulan \\
\hline Kepuasan Kerja & 1,032 & 0,305 & Ditolak \\
Komitmen & 0,293 & 0,771 & Ditolak \\
$\begin{array}{c}\text { Organisasi } \\
\text { Lingkungan Kerja }\end{array}$ & 4,063 & 0,000 & Diterima \\
\hline
\end{tabular}

\section{d. Analisis Koefisien Determinasi $\left(\mathbf{R}^{2}\right)$}

Perhitungan $\mathrm{R}$ square dilakukan untuk mencari hubungan antara variabel independen dan variabel dependen. $\mathrm{R}^{2}$ merupakan angka yang menjelaskan variasi variabel dependen. Hasil uji dari analisis koefisien determinasi $\left(\mathrm{R}^{2}\right)$ dalam penelitian ini sebagai berikut:

Tabel 4.16

Hasil Uji Koefisien Determinasi

\begin{tabular}{ccc}
\hline $\mathrm{R}$ & $\mathrm{R}$ Square & Adjusted R Square \\
\hline 0,466 & 0,217 & 0,192 \\
\hline
\end{tabular}

\section{Pembahasan}

a. Hasil uji F diketahui bahwa kepuasan kerja, komitmen organisasi dan lingkungan kerja secara simultan berpengaruh signifikan terhadap turnover intention karyawan bagian Sewing PT Dan Liris dengan nilai Fhitung sebesar 6,730 dan nilai signifikansi lebih rendah dari level of significant yaitu $(0,000<0,05)$. 
b. Hasil uji t diketahui nilai signifikansi variabel kepuasan kerja sebesar 0,305 >0,05. Artinya variabel kepuasan kerja secara parsial berpengaruh positif tapi tidak signifikan terhadap turnover intention karyawan bagian Sewing PT Dan Liris. Sehingga ini menunjukkan adanya karyawan yang merasa tidak puas terhadap pekerjaannya namun memilih tetap bertahan untuk bekerja di perusahan tersebut.

c. Hasil uji t diketahui nilai signifikansi variabel komitmen kerja sebesar 0,771>0,05. Artinya variabel komitmen oorganisasi secara parsial berpengaruh positif tetapi tidak signifikan terhadap turnover intention karyawan bagian Sewing PT Dan Liris. Hal ini menunjukkan adanya karyawan yang tidak memiliki komitmen terhadap organisasi, karena mereka hanya sekedar bekerja dan pasif (tidak mau terlibat aktif terhadap semua kegiatan perusahaan).

d. Hasil uji t diketahui nilai signifikansi variabel lingkungan kerja sebesar $0,00<0,05$. Artinya variabel komitmen organisasi secara parsial berpengaruh positif dan signifikan terhadap turnover intention karyawan bagian Sewing PT Dan Liris. Hal ini menunjukkan adanya karyawan yang tetap memilih tidak bertahan untuk bekerja di perusahaan. Hal ini dapat dilihat dari data karakteristik responden bahwa sebagian besar karyawan berada di usia 18-28 tahun, dimana pada usia produktif ini seseorang akan memiliki mobilitas tinggi, membutuhkan lingkungan kerja yang bebas untuk mengekspresikan diri dan penuh tantangan.

\section{KESIMPULAN}

Berdasarkan hasil dan pembahasan pada bab IV tersebut diatas, maka peneliti memberikan kesimpulan sebagai berikut:

1) Kepuasan kerja, komitmen organisasi dan lingkungan kerja secara simultan atau bersamasama berpengaruh signifikan terhadap turnover intention karyawan bagian Sewing PT Dan Liris.

2) Kepuasan kerja secara parsial berpengaruh positif tetapi tidak signifikan terhadap turnover intention karyawan bagian Sewing PT Dan Liris. Kepuasan kerja merupakan perasaan yang dirasakan karyawan terhadap kondisi ia bekerja baik berupa perasaan positif atau negatif. Berdasarkan pengamatan, masih terdapat karyawan yang tidak puas terhadap pekerjaannya namun memilih bertahan untuk bekerja pada perusahaan tersebut. Hal ini dikarenakan karyawan masih membutuhkan pekerjaan tersebut dan semakin sulitnya mencari pekerjaan baru.

3) Komitmen organisasi secara parsial berpengaruh positif tetapi tidak signifikan terhadap turnover intention karyawan bagian Sewing PT Dan Liris. Komitmen organisasi merupakan kondisi dimana karyawan merasa betah/ingin bertahan di perusahaan dalam waktu lama. Berdasarkan pengamatan, masih terdapat karyawan yang tidak memiliki komitmen organisasi. Hal ini terlihat ketika mereka hanya sekedar bekerja dan pasif, tidak mau terlibat aktif terhadap kegiatan pencapaian tujuan perusahaan.

4) Lingkungan kerja secara parsial berpengaruh positif dan signifikan terhadap turnover intention karyawan bagian Sewing PT Dan Liris. Lingkungan kerja merupakan semua kondisi baik lingkungan fisik dan non fisik yang mempengaruhi karyawan dalam bekerja. Berdasarkan pengamatan, terdapat karyawan yang tetap memilih tidak bertahan untuk bekerja di perusahaan. Hal ini dapat dilihat dari data karakteristik responden bahwa sebagian besar karyawan berada di usia 18-28 tahun, dimana pada usia produktif ini seseorang akan memiliki mobilitas tinggi, membutuhkan lingkungan kerja yang bebas untuk mengekspresikan diri, haus akan tantangan dan cenderung tidak loyal terhadap perusahaan. 


\section{DAFTAR PUSTAKA}

Firdaus, Ahmad. (2017). Faktor-Faktor Yang Mempengaruhi Turnover Intention (Studi Pada

Karyawan Perusahaan Jasa Multi Finance Di Kota Jambi). Jurnal of Economics and Business, Vol. 1, No. 21

Fuaidah, dkk. (2018). Pengaruh Kompensasi Karyawan dan Lingkungan Kerja Terhadap Turnover Intention. (Studi pada Karyawan Auto 2000 Malang-Sutoyo). Jurnal Administrasi Bisnis (JAB). Vol 60, No. 2.

Indrayanti \& Riana. (2016). Pengaruh Kepuasan Kerja Terhadap Turnover Intention Melalui Komitmen Organisasional pada PT Ciomas Adiwisata di Denpasar. Vol. 5, No. 5.

Rismayanti, dkk. (2018). Pengaruh Kepuasan Kerja Terhadap Turnover Intention Serta Dampaknya pada Karyawan (Studi Pada Karyawan Tetap Pg Kebon Agung Malang). Jurnal Administrasi Bisnis(JAB).Vol. 61, No. 2.

Setiyanto \& Hidayati. (2017). Pengaruh Kepuasan Kerja dan Komitmen Organisasi terhadap Turnover Intention. Vol. 5, No.11. 